\title{
SPATIAL BORDERS OF A REAL-ESTATE OWNERSHIP TITLE UNDER PRESENT LEGAL CONDITIONS IN POLAND
}

\author{
Jadwiga Konieczna, Agnieszka Trystula \\ University of Warmia and Mazury in Olsztyn, Poland \\ jadwiga.konieczna@uwm.edu.pl, agnieszka.trystula@uwm.edu.pl
}

\begin{abstract}
In the broadly understood process of real estate management owners and users as well as other entities participate, inter alia, banks, courts, notaries, appraisers, managers and intermediaries in property transactions, investors, construction supervision services, and architectural and construction administrative bodies, for which up-to-date, complete information on real estate is a prerequisite for taking appropriate decisions. Since 1989, real estate, and thus information on it, has become an important element of the economic development and functioning of the State. One can point to the significance of real estate to spatial management and proper spatial planning, the realisation of investments, the tax system, or the activities of government and local government administration. A real-estate, as a basic registry item in a real-estate cadastre, features geodetic borders determined in two dimensions, i.e. on a horizontal plane of the Earth. Such borders delimit only one area of the influence of an ownership title in relation to its surface area. Art. 143 of the Civil Code states that within the borders determined by social and economic purpose of land, the ownership of land extends over the area over and below its surface and that a land real-estate is not a place but rather a solid delimited by vertical planes.
\end{abstract}

Keywords: real estate, property rights, boundaries.

\section{Introduction}

In considering the three types of property (land property, building property, and premises property), the issue of land property spatial boundaries appears to be very complex. A definition of land property is provided in two Polish legislative acts, namely, in the Civil Code Act of 23 April 1964 (consolidated text in Journal of Laws of 2016, Item 380, as amended) and in the Real Estate Management Act of 21 August 1997 (consolidated text in Journal of Laws of 2015, Item 1774, as amended). According to Article $46 \S 1$ of the Civil Code, "Real estate is part of the earth's surface constituting a separate object of ownership (land), as well as buildings permanently attached to the land or parts of such buildings if, under specific regulations, they constitute an object of ownership separate from the land." On the other hand, Article 4(1) of Real Estate Management Act provides that "land property is land along with component parts, with the exception of buildings and premises if they constitute a separate object of ownership."

Right of ownership is the widest form of the use of things provided for in Polish legislation. The strongest right to use, derive benefits and dispose of property, e.g. transfer of ownership right through purchase-sale, donation, exchange, release for perpetual usufruct, leasing on the grounds of an agreement. However, the right of ownership does not give full control over a property and it is not executed in isolation from other entities but within a certain space in which both the owner' interests and the needs of the public as well as the economic aspect of the use of property need to be taken into account. Restrictions on the right of ownership arise from regulations, principles of social coexistence or socio-economic designation of a property.

Ownership right to a separated area of land would be uncertain and difficult to be legally protected if it did not have strictly marked boundaries that determine the area within which the owner is able to exercise their rights. Constitutional strengthening of the right of ownership results in a new approach to the issue of boundaries which determine the extent of this right within a space.

The aim of the study is to present legal issues related to the introduction in Poland of the principles of defining spatial borders of real estate. The research applied the following methods: analysis and synthesis of the literature and law and method of conclusion.

\section{Property boundaries}

The earliest type of boundaries was the boundaries of areas. Typically, these were natural boundaries, e.g. mountain ranges, rivers, and forest complexes. The first problems associated with the determination of land property boundaries arose only after the development of the right of land ownership, along with the beginning of marking and fixing these boundaries on the ground with boundary markers [1]. 
A property, as part of the earth's surface, is identified by its boundaries. Property boundaries specified within an area through laying out of markers and the course of boundary lines outline the extent of ownership right in relation to the adjacent land within the space. Therefore, a boundary identifies a property as an object of legal transactions. A property may comprise one or many (cadastral) parcels which do not necessarily have to be adjacent to one another, given the fact that the condition of continuity need not to be satisfied and that one property may comprise many plots which are not adjacent to one another. The boundaries of these plots are, at the same time, boundaries of the property. No area of Poland exists that is not part of a property or constitutes a property. As already mentioned, physical separation of a property is performed through the determination of the position of boundary points within an area (coordinates X, Y) and the course of boundary lines within an area, the determination of its surface area and marking that enables unambiguous identification. Legal separation of a property is effected through the determination of an entity who owns the property rights to a part of the earth's surface separated with boundaries. Therefore, boundaries specify the legal status of the property, disclosed in Sections II-IV of the land and mortgage register [2].

In Polish legislation, methods for determining the course of boundaries are governed by provisions of the Act of 17 May 1989 - Geodetic and Cartographic Law (consolidated text, Journal of Laws of 2015, Item 520, as amended) and relevant implementing provisions, and in the Regulation of Minister of Regional Development and Construction of 29 March 2001 on the Land and Property Register (Journal of Laws of 2016, Item 1034), and the Regulation of Minister of the Interior and Administration of 9 November 2011 on technical standards for the performance of topographic surveys and for the compilation and transmission of the survey results to the National Land Surveying and Cartographic Database (Journal of Laws of 2011, No 263, Item 1572, as amended).

According to the Geodetic and Cartographic Law Act, the determination of the course of property boundaries may take place in the following modes:

- delimitation of properties,

- recovery of boundary marks,

- designation of boundary points previously disclosed in the Land and Property Register.

Furthermore, provisions of \$37-39 of the Regulation on the Land and Property Register provide for the procedure for determining the course of cadastral plot boundaries.

The actual physical location of a boundary line is usually marked by point characteristics, or boundary points, in which a boundary mark (e.g. a concrete post) is placed, or using such linear characteristics as fences, walls, hedges and boundary strips. Where a physical point (boundary mark) on the earth's surface where the boundary turns, is surveyed (ordinate, abscissa, sight line length and angle, coordinates $\mathrm{X}, \mathrm{Y}$ ), a mathematical presentation of that boundary point will be obtained. However, in certain cases, particularly where open development or sheets of water are involved, no physical sign of the boundary exists. Its location may be deduced, e.g. by analysing the records of cadastral maps. Physical signs of boundaries have an important social function, as they show the extent of the areas belonging to particular people.

Legal boundaries designated within two dimensions (X, Y) identify a property spatially as a part of the earth's surface; unfortunately, they only designate one area of the impact of the right of ownership. A property, as part of the earth's surface, is a spatial formation, and the right of ownership also extends to the space over and under its surface, up to a specified height and down to a specified depth defined in legal systems of particular states. This is because the rule arising from Roman law, according to which the ownership of land extends both deep into the earth, down to the centrosphere, and upwards to include an air column of unlimited height over the land, is unacceptable in present times.

\section{Restrictions on the use of the space over and under the surface in accordance with applicable polish regulations and examples of legal solutions in the use of the space "over" and "under" the land surface - results and discussion}

An important current issue is the question of whether a land property is a three-dimensional or two-dimensional structure. The prevailing view is that a land property is a structure with three dimensions; therefore, it has its horizontal and vertical limits. In fact, the discussion boils down to 
providing an answer to the questions as to whether a land property as a thing is a plane, with the right of ownership extending to the space "over" and "under" that plane, or whether a land property as a thing is a solid, with the extent of the right of ownership being determined by the vertical limits of that solid [3].

In Poland, considerations of the vertical limits of a property are based on the interpretation of the provision of Article 143 of the Civil Code, which provides that "within the limits set by the social and economic purpose of land, the ownership of land extends to the space over and under its surface. This provision does not prejudice regulations on rights to waters." Therefore, the social and economic purpose of land is currently the basic criterion for determining the vertical extent of property ownership.

One of the issues is to determine who, and according to which rules, has the right to extract minerals, and which entity is the owner of these minerals. In Polish legislation, this issue has never been resolved in an unambiguous manner. Neither provisions of the interwar period nor the Mining Law of 1953 governed the issue of mineral deposits exhaustively [4]. Currently, the legal situation of the space "under a (land) property", alternatively referred to as ownership of earth interior and, in particular, ownership of mineral deposits, was settled in Article 10 of the Act of 9 June 2011 Geological and Mining Law (consolidated text, Journal of Laws of 2015, Item 196, as amended). The Act in question, which replaced the previous Act of the same title of 1994, introduced a number of significant changes to ownership relations as regards mineral deposits. According to Article 10(1) of the Act as follows.

1. "Deposits of hydrocarbons, hard coal and methane occurring as accompanying mineral, lignite, metal ores with the exception of bog iron ores, metals in the native state, ores of radioactive elements, native sulphur, rock salt, potassium salt, potassium and magnesium salt, despite the place of their occurrence, are covered by mining ownership.

2. Deposits of curative waters, thermal waters and brines are also covered by mining ownership.

3. Deposits of minerals not listed above in (1) or (2) are covered by the right of land property ownership.

4. Mining ownership also covers parts of the rock mass located outside the spatial limits of the land property, in particular, those located within the limits of maritime areas of the Republic of Poland.

5. The right of mining ownership is owned by the State Treasury."

Pursuant to Article 12(1), the State Treasury, with the exclusion of other persons, may benefit from the object of mining ownership or exercise its right exclusively by the establishment of mining usufruct. The establishment of this right shall be effected by way of a written agreement which shall come into effect on the date of obtaining the licence. The agreement provides a basis for determining the remuneration for the establishment of mining usufruct and the manner of payment.

The criterion of social and economic purpose of land also determines the limits over the surface. Restrictions on the use of the space "over" the property arise from provisions of the Act of 3 July 2002 - Aviation Law (consolidated text Journal of Laws of 2016, Item 605). In practice, the used of the space over land properties by third parties is related to aircraft flights. Article 4(1) of the Act provides that: "The Republic of Poland has complete and exclusive control of its airspace...". According to the cited article, the state's control of the airspace results in a restriction on the right of ownership within the vertical limits "over" the property surface. Restrictions on the right of ownership arise from the established rules for a flight within the airspace and from prohibitions imposed on the construction and extension of civil structures referred to in Article 87(6) of the Act in the vicinity of an airfield, namely, within $5 \mathrm{~km}$ from the airfield boundary. However, the provision of Article 87(7) is also important, as it prohibits the planting and cultivation of trees and bushes on properties located within the areas of landing approach, which may be an air traffic obstacle; the obligation to remove the trees and bushed concerned shall be fulfilled, and the costs of the removal shall be borne by the owner or another entity holding the property.

The legal situation of land under waters is currently governed by the Act of 18 July 2001 - the Water Law (consolidated text, Journal of Laws of 2015, Item 469), which provides in Article 1a that it shall be applied in cases concerning the ownership of waters and land covered by waters. These matters are settled by provisions of Article 10(1a) and Article 12(1), which provide for the following: 
- waters of the territorial, internal sea waters including those of the Gulf of Gdańsk, inland surface running waters and underground waters shall be owned by the State Treasury.

- standing waters and waters in ditches found within the boundaries of a land property shall be owned by the owner of the property.

According to Article 36(1), "the owner of land shall have the right to normal use of the water he/she owns, and of the underground water found in his/her land; this right shall not constitute the right to construct water facilities without the required water permit."

The cited provisions stipulate that the spatial limits of a land property only reach a certain height and depth, which is determined by the criterion of social and economic purpose of land, and the applicable regulations enable the use of the airspace of another land property.

The ideas for the development of unused development rights appear in locations where land is of a very high value, e.g. in large cities under pressure of further development, in which undeveloped "air plots" still exist over low historical buildings, churches, schools, railway stations, and over streets, roads and railway tracks lowered in excavations [5].

Legal solutions enabling the use of the space over and under the land surface have been present in Anglo-Saxon legal systems for years, an example of which could be the transfer of development rights existing in the USA, i.e. the transaction of the right to the development of a part of the surface, in which the object of transaction may be a strictly determined (height, depth, extent) space itself, located directly over or under the land surface [6].

In accordance with American law, the material extent of the right of ownership to which the property owner is entitled also covers the space situated directly over and under the surface of the legally designated area of land. Judicial decisions of American courts have established the common law, according to which the powers of a land property owner extend in space up to a height of $200 \mathrm{~m}$ counting from the surface of the roof of the building situated on the land concerned. In the system of American law, the defined space constitutes a property separate from the land and is referred to as an air plot, which may be an object of separate ownership. The owner of a land property may sell the defined air rights which belong to him/her to an entity that is planning to implement an investment project running at a certain height over his/her land [7].

The concept of spatial right of ownership has also been introduced by certain European countries, including Sweden, Norway, or Denmark.

In Sweden, the concept of three-dimensional ownership has been introduced to legal circulation as a result of the 2004 amendment to the Land Code, and the adoption of the Act on the creation of properties. A possibility has been approved for the performance of the division of a property in relation to both the land itself and the space over and under its surface, provided that the division of an air plot, given its specificity, shall be governed by separate rules. The possibility for the legal separation of a three-dimensional property has been reserved in Swedish legislation only for cases where the application of such a solution increases the guarantees of achieving the set investment objectives, and of the legal and economic protection of the project being implemented. One of the conditions underlying the possibility for the separation of an air plot is the need to ensure that the prospective buyer has the so-called bundle of rights that provides him/her with the access to this space, and its proper use. Swedish law excludes the possibility for the separation of an air plot that includes e.g. higher floors of a building without ensuring, at the same time, access to them via a common staircase or a lift. After the 2009 amendment of regulations, in Sweden there is a legal possibility for the separation of an "empty" air plot, provided, however, that the investor presents a valid permit for the construction of a structure. The rules for the separation of an air plot are specified in the Act on the Creation of Properties and are implemented in terms of the cadastral procedures related to the property division and consolidation, which are listed in the Act. The limits of a spatial property are determined using coordinates $(\mathrm{x}, \mathrm{y}, \mathrm{z})$ of the points defining its extent, or defined using a descriptive method in relation to the existing walls, intermediate floors, roofs, etc. The separated properties are registered in the cadastre $[8 ; 9]$.

In Norway, works associated with defining the concept of a three-dimensional property were initiated in 1992. A concept was then developed that enables the separation of an "air plot" within the spatial limits to which the owner of the land property is entitled. In accordance with Norwegian law, 
spatial limits of the right of ownership are restricted by the so-called general clause which determines reasonable and economical exploitation. According to the current law, the separation of a land property is determined by the previous acquiring of building permit by the investor, which is issued for a period of 3 years, provided, however, that the possibility for the separation of an air plot is only acceptable for the already existing buildings or land plots, on the surface of which such construction is being performed. An air plot may be legally separated as a result of the implementation of the property division procedure, which leads to its spatial parameters ( $x, y, z)$ being marked, or as a result of the establishment of usufruct on a land plot. As regards the separation of an air plot, the investor acquires the right of ownership, which is required to be registered in the cadastre [10].

\section{Conclusions}

Innovative spatial management, particularly in large cities, requires legal decisions as regards the use of underground and aboveground space in order to maintain the legal order, and improve investment processes. This concerns inter alia the implementation of line investment projects which are to run above the surface of many land properties, the construction of enclosed walkways above the street, the construction of underground car parks, or the right to the development above low buildings in the centres of large cities, where local plans allowed the intensity of development to be higher than the current one. The use of the space under and over the land is a way of removing barriers to development.

It is clear from the analysis of current legislation that we are dealing with the "layered " of property rights. The use of space within certain vertical limits by various entities requires both legal and technical means of determining the vertical limit. In this field, Poland has no specific legal solutions defining an air plot, or decisions concerning the establishment of vertical limits of properties. The issue of property spatial limits involves the issue of a 3D cadastre.

Not only should a 3D cadastre include the possibility for recording geometrical data $(x, y, z)$ concerning three-dimensional cadastral objects, but it should also include the spatiotemporal rights established on other properties [7].

\section{References}

1. Hycner R. Podstawy katastru. (Cadastre). University of Science and Technology, Kraków 2004, pp. 33-34 (in Polish).

2. Konieczna J. Wprowadzenie do katastru nieruchomości. (Introduction to the cadastre). Texter, Warsaw 2016, pp. 82-103 (in Polish).

3. Matusik G. Tytuły prawne pozwalające na korzystanie z przestrzeni „pod” powierzchnią gruntu. (Legal titles allowing the use of space "under" the surface of the land). Proceedings of National conference „Spatial management "over "and "under "land”, Katowice 2011, pp. 58-59. (in Polish).

4. Nych E. Własność złóż kopalin. (Property of mineral deposits). Proceedings of National conference „Natural hazards in mining”, Katowice 2009, pp. 257-265. (in Polish).

5. Brzeski W. Trendy światowe w wykorzystaniu przestrzeni „,nad” i ,pod” gruntem - przykłady z USA. (World trends in the use of "over" and "under" space - examples from the USA). Proceedings of National conference „Spatial management "over "and "under "land”, Katowice 2011, pp. 21-22. (in Polish).

6. Sandberg H., 2009. Three-Dimensional Division and Registration of Title To Land, Legal Aspects. [online] [10.03.2017]. Available at: www.gdmc.nl/3DCadastres/literature.

7. Felcenloben D. Czasowo-przestrzenne obiekty ewidencyjne $\mathrm{w}$ wielowymiarowym katastrze nieruchomości - perspektywa zmian istniejącego modelu. (Temporal spatial property registration in a multidimensional real estate cadastre - potential changes to the existing model). Journal Acta Scientiarum Polonoru Geodesia et Descriptio Terrarum, vol. 12, No 1/2013, Poland, pp. 10-15. (in Polish).

8. Eriksson G., Adolfsson C., 2006. Experiences of the 3D Cadastre Legislation, Shaping the Change - XXIII FIG Congres, Munich, Germany. [online] [09.03.2017]. Available at: www.gdmc.nl/3DCadastres/literature. 
9. Karabin M. Analiza istniejących rozwiązań w zakresie katastrów trójwymiarowych (tzw. 3D) w wybranych krajach Unii Europejskiej. (Analysis of existing solutions in the field of threedimensional (3D) cadastral systems in the European Union states). Journal Geodetic survey No 12. Warsaw 2007, pp. 14-15. (in Polish).

10. Valstad T., 2003. The Oslo Method: a practical approach to register 3D properties. FIG Working Week, Paris, France. [online] [10.03.2017]. Available at: www.gdmc.nl/3DCadastres/literature. 